\title{
La hacienda de Ciénega de Mata, desde su formación hasta el fin de la reforma agraria
}

\author{
Cienega de Mata, from their Beginning \\ to the End of the Agrarian Reform \\ Jesús Gómez-Serrano \\ Universidad Autónoma de Aguascalientes, Aguascalientes, México, \\ email: jgomez@correo.uaa.mx
}

Resumen. Ciénega de Mata, uno de los más extensos y productivos latifundios de la Nueva Galicia, empezó a formarse a fines del siglo XVI y permaneció indiviso hasta 1861, cuando su último propietario repartió las haciendas que lo integraban entre sus hijos y vendió gran cantidad de ranchos entre sus arrendatarios. En el siglo XX, el agrarismo revolucionario liquidó el régimen de haciendas y trasladó masivamente las tierras a manos de los campesinos; la que fuera la cabecera del latifundio perdió más de la mitad de sus tierras, y el resto se dividió en tres pequeñas propiedades. Apoyado en fuentes primarias, se propone un repaso de la historia de este latifundio; aunque se hace cierto énfasis en algunas coyunturas, también se propone una visión de largo plazo, habitualmente ausente en la historiografía referida al tema.

Palabras clave: latifundismo; reforma agraria; pequeña propiedad; gestión de haciendas.

Summary. Ciénega de Mata, one of the most extensive and productive latifundia of the New Galicia, began to form at the end of the sixteenth century and remained undivided until 1861, when its last owner shared the haciendas that integrated it among their children and sold a large number of ranches among its tenants. In the twentieth century, revolutionary agrarianism liquidated the hacienda regime and massively moved the land to the hands of peasants; the one that was the head of the latifundio lost more than half of its earth and the rest was divided in three small properties. Supported primary sources, it is proposed a review of the history of this latifundio; although some emphasis is placed on some conjunctures, a long-term view is also proposed, usually absent in the historiography related to the topic.

Keywords: great landowner; agrarian reform; small property; hacienda management.

JEL: N8; N96; O12; O18.

Fecha de recepción: 6 de enero de 2017. Fecha de aceptación: 28 de abril de 2017.

Am. Lat. Hist. Econ., sep.-dic., 2017, pp. 130-160 | DOI: 10.18232/alhe.v24i3.860 


\section{INTRODUCCIÓN}

partir de la publicación del trabajo de Chevalier (1976) se han mul-
tiplicado los estudios sobre la tenencia de la tierra y el desarrollo
agrícola, lo que ha permitido abrir nuevos campos de investigación y escribir una historia rural del país muy diferente de la que se hacía a la sombra de los logros de la reforma agraria. A ese trabajo pionero se ha añadido una cantidad impresionante de libros y artículos, en cuya gran diversidad puede advertirse un punto de unión: el enfoque regional. En resumen, según afirma Eric Van Young (1989, p. 17) "muchas de las nuevas concepciones de la historia agraria mexicana han surgido de las investigaciones de la estructura social y económica regional". En palabras de Tortolero (1998, p. 21), "sólo los estudios regionales" nos pueden indicar el peso exacto que tenían "las haciendas, las comunidades y los ranchos" en la economía rural del país.

En el contexto de la actual discusión historiográfica, proponemos un ensayo de historia rural centrado en la evolución de un latifundio particular, lo cual se justifica en el caso de México dada la preeminencia de la gran hacienda (Van Young, 1992, pp. 126-127). El enfoque monográfico puede considerarse limitante, pero debe tenerse en cuenta que no se trata de una hacienda cualquiera, sino de un caso que "bastaría por sí solo para ilustrar bajo sus diferentes aspectos el proceso de concentración de la propiedad" (Chevalier, 1976, p. 220). Además, proponemos una visión de largo plazo, lo cual es infrecuente en nuestra historiografía, que ha hecho de las mojoneras construidas con propósitos de periodización obstáculos infranqueables (Fujigaki, 2006).

El latifundio de Ciénega de Mata se formó lentamente, en el contexto de la expansión española al norte, y alcanzó su mayor extensión en el siglo XVIII. Durante la primera mitad del siglo XIX se impusieron nuevas ideas sobre la propiedad de la tierra, en concreto la necesidad de subdividir las grandes haciendas, lo que hace más notable el hecho de que este latifundio haya permanecido intacto hasta 1861 , cuando su último propietario repartió las haciendas entre sus hijos y vendió los ranchos a sus antiguos arrendatarios. Proponemos como hipótesis que este episodio debe entenderse en el contexto de los intentos hechos por los liberales para "resolver el problema de la tierra" (Reyes, 1982, vol. III, p. 618) y que puede considerarse un precedente de la gran reforma agraria emprendida por la revolución triunfante. Aparte de su escala, la gran diferencia consiste en que el principal agente de esa reforma fue la pequeña propiedad independiente, no el ejido colectivo tutelado por el Estado. Aunque se ha despreciado la tendencia a la fragmentación de la gran propiedad que se observa a lo largo de todo el siglo XIX, se trata de un tema de enorme importancia, como 
lo demuestran, una vez más, los estudios locales (Bazant, 1980, 1982; Brading, 1988; García, 1992; Gómez, 2000; González, 1979).

El programa de la revolución triunfante incluía la restitución a los pueblos de indios de las tierras de las que habían sido despojados y la consideración de que los peones de las haciendas podían obtenerlas mediante dotación, lo que tuvo graves consecuencias en Ciénega de Mata y otras muchas fincas en las que no había comunidades indígenas. Ahora sabemos que los gobiernos de la posrevolución no acabaron con la desigualdad en el campo, pero lograron algo crucial en términos de la estabilidad del régimen: liquidar a la hacienda como estructura de poder y convertir a los campesinos beneficiados por el reparto agrario en una clientela política bien organizada (Hurtado, 2004, p. 15; Knight, 2013, pp. 42-47). Este artículo muestra las consecuencias que tuvo la reforma agraria en Ciénega de Mata, la hacienda madre del antiguo latifundio, que fue la única que permaneció en manos de la familia Rincón Gallardo.

\section{FORMACIÓN Y DESARROLLO DEL LATIFUNDIO}

La formación de este latifundio se remite a las mercedes concedidas en el ocaso del siglo XVI a Pedro Mateos, un labrador originario de Extremadura (Alcaide, 2004, pp. 32-36; Tuttino, 2016, p. 178). La estafeta fue recogida por sus nietos, Agustín y Pedro Rincón de Ortega, que ensancharon el dominio familiar y le dieron a la propiedad de la tierra un sentido de empresa. En su testamento, ${ }^{1}$ el cura Pedro Rincón indicó su voluntad de formar un mayorazgo con sus bienes, aunque no dio pasos más concretos en esa dirección. La debilidad jurídica de este documento no impidió que José Rincón Gallardo, su sobrino nieto, tomara posesión en 1683 de los bienes vinculados a la casa de Ciénega de Mata. ${ }^{2}$ En 1703, con el propósito de familiarizar a su hijo con el gobierno de sus haciendas, José redactó una Memoria (Gómez y Delgado, 2005, 187-222) que resume la experiencia que la familia acumuló a lo largo del siglo XVII. En contra de esa imagen tan extendida de los latifundistas como hombres ajenos a las exigencias de la vida del campo, esta Memoria, anterior a la célebre Instrucción de los jesuitas, retrata a un propietario que administra con inteligencia sus negocios y usa criterios de racionalidad (Chevalier, 1976, p. 297 y Denson, 1978, pp. $243 y$ 271).

${ }^{1}$ Cláusula 97 del testamento otorgado en la villa de Aguascalientes el 10 de marzo de 1657, ante Agustín Pérez y Calderón, escribano público de la villa de Tacuba. La transcribe Manzano, 1728, if.

${ }_{2}^{2}$ Archivo General de la Nación (en adelante AGN), Tierras, vol. 482, 96f-134v. 
Azuzada por su marido, María Teresa Rincón Gallardo intentaría en 1726 destruir la tesis del vínculo y quedarse con las haciendas, que según sus abogados formaban un fideicomiso. Esa fue la prueba de fuego que tuvo que sufrir el mayorazgo y la decisión final se tomó a nivel del Consejo de Indias, en Madrid, en 1734, con una sentencia que reconocía la existencia del vínculo y a Francisco Javier Rincón Gallardo como su legítimo poseedor. ${ }^{3}$ Para entonces, el latifundio había alcanzado su máxima extensión: 83 sitios de ganado mayor y menor y 219 caballerías de tierras de labor (360 000 ha), un inmenso rectángulo enclavado en el noreste de la Nueva Galicia; ${ }^{4}$ un verdadero principado en pequeño, según la caracterización de Chevalier (1976, pp. 220-221). Durante el siglo XVIII se integraron poco a poco unidades productivas diferenciadas al interior del latifundio, se formaron ranchos y sus arrendatarios abrieron tierras a la labor. A fines de la época colonial el latifundio era lo suficientemente rico para sustentar la pretensión de Manuel Rincón Gallardo de ser investido como caballero de la Orden de Santiago y de obtener el título de marqués de Guadalupe. ${ }^{5}$ La expansión agrícola y ganadera se sustentó parcialmente en el trabajo de los esclavos, muchos de los cuales vivían en realidad libremente, como mayordomos, artesanos o vaqueros (Tuttino, 2016, pp. 230-232).

El mayorazgo y el título fueron a parar a manos de José María Rincón Gallardo, segundo marqués de Guadalupe y sexto titular del vínculo. En septiembre de 1816 fue nombrado teniente coronel y tomó el mando de los Urbanos de Ciénega de Mata, lo que le permitió sumarse a los esfuerzos tendentes a asfixiar los movimientos de las guerrillas insurgentes (Zayas, s. a., pp. 129-131). La hacienda de Ciénega fue convertida en una fortaleza "inexpugnable" (Beltrami, 1982, p. 259) y su defensa corría por cuenta de una compañía de patriotas formada por vaqueros, pastores, labriegos e inquilinos de la casa, e incluso "insurgentes amnistiados" (Hamnett, 1990, pp. 222, 235).

En un principio, el joven marqués de Guadalupe tuvo dudas sobre los alcances de la conspiración de Iturbide, pero cuando el panorama se aclaró se sumó a quienes en la región aplaudían al libertador. ${ }^{6}$ Iturbide retribuyó con generosidad sus servicios, pues lo hizo coronel del ejército y caballero de la Orden de Guadalupe, "el último sitio en el que los nobles aparecieron ostentosamente en público como cortesanos" (Ladd, 1984, p. 200).

${ }^{3}$ Archivo Colonial de la Familia Rincón Gallardo (en adelante ACFrg, caja 15, exp. 1).

${ }^{4}$ ACFRG, caja 1, exp. 1, fs. $117 \mathrm{v}-123 \mathrm{f}$.

${ }^{5}$ AGN, Vínculos y mayorazgos, vol. 250, exp. 9, 1810.

${ }^{6}$ Archivo privado del general José María Rincón Gallardo (en adelante AJMrG), caja 28, exp. 394 , f. 1 . 
La abolición de los mayorazgos fue ratificada por el Congreso mexicano en 1823 mediante un decreto que daba a sus titulares la posibilidad de disfrutar en forma libre de la mitad de los bienes vinculados, reservando la otra mitad a quien lo sucediera en forma inmediata. ${ }^{7}$ Los efectos de esta disposición fueron muy desiguales, pues de algunos mayorazgos no quedó en pocos años ni el menor rastro, mientras que otros fueron capaces de mantenerse indivisos y seguir prosperando. En todo caso, era la propia elite la primera interesada en la abolición de la propiedad vinculada, pues ello le permitió especular "sin las regulaciones ni la supervisión del gobierno" (Ladd, 1984, pp. 228-239).

\section{La Gestión de José MaRÍa RinCón Gallardo}

Todo ello nos ayuda a entender la decisión de José María Rincón, quien solicitó su baja del ejército y se retiró a Ciénega de Mata con el propósito de entenderse directamente de sus haciendas. Aunque la extinción de la propiedad vinculada le permitía fraccionarlas y venderlas, su agudo sentido empresarial le aconsejó mantenerlas unidas, convirtiéndolas en un próspero negocio. Así sorteó la primera mitad del siglo XIX; mientras el país se deshacía en medio de interminables guerras civiles, él hacía de Ciénega de Mata la base de una inmensa fortuna. Sin duda, era uno de esos nobles que se empeñaron en lucrar, como burgueses, "con lo que ya no tenía sentido conservar como aristócratas” (Domínguez, 2004, pp. 654-656).

Ciénega de Mata era una de las haciendas "más extensas y ricas de México", su casa grande era un "palacio vasto y cómodo", su iglesia estaba "bien decorada" y el cura era "un monje con sentido común" que hacía sus negocios "con moderación y sin escándalo", pero su dueño no era "un satélite del despotismo y de la tiranía", sino "uno de los mejores criollos, librepensadores y lleno de sentimientos generosos" (Beltrami, 1982, pp. 260-261). En un sentido parecido, el ministro inglés Ward (1981, p. 674) calculó que Ciénega de Mata le dejaba a su propietario una renta anual de 75000 dólares.

Estos testimonios ilustran el excepcional talento empresarial que tenía el último mayorazgo de Ciénega de Mata, quien mejoró sus haciendas y procuró su especialización productiva. La hacienda de Chinampas, por ejemplo, que en la época de la guerra de Independencia "no era más que un llano", contaba en 1829 con su propia casa grande, casas para los peo-

${ }^{7}$ Dublán y Lozano, Legislación mexicana, t. I, núm. 347, pp. 662-664. Recuperado de http:// cdigital.dgb.uanl.mx/la/1080042593_C/1080042593_T1/1080042593_120.pdf 
nes, "trojes donde caben más de mil carretas de maíz [...] y todas las demás oficinas necesarias para una hacienda". ${ }^{8}$

José María Rincón vivió con el siglo y se fue adaptando a las cambiantes circunstancias políticas. Nació en el ocaso de la época virreinal pero creció y se hizo hombre como mexicano. Compartió los sueños imperiales de Iturbide, experimentó el fracaso de la primera república federal y del experimento centralista, vivió el desastre de la guerra contra Estados Unidos y la humillación de los tratados de Guadalupe, depositó sus esperanzas en el último gobierno de Santa Anna, siguió de cerca los debates del Congreso Constituyente de 1856, el triunfo liberal, la guerra de los Tres Años y el imperio de Maximiliano, en el que creyó, como muchos otros mexicanos. Todavía le alcanzó la vida para ver el restablecimiento de la república, la revolución de Tuxtepec y el triunfo de Porfirio Díaz. La suya fue una época llena de turbulencias y grandes fracasos. Murió en su hacienda de Ledesma el 21 de septiembre de 1877, cuando el poder del general Díaz aún no se afianzaba y se seguían dibujando en el horizonte negros nubarrones, la promesa cierta de nuevas asonadas.

Su abolido título nobiliario y su riqueza hacían de él un típico representante del ancien régime, pero por eso mismo resulta sorprendente la habilidad con que supo conducir su nave en las aguas revueltas de la política, al extremo de que los fracasos del país no pusieron en peligro sus negocios. Era amigo de Santa Anna y consuegro de uno de sus más cercanos colaboradores, el general Tornel. En enero de 1835 reinició su carrera militar, aceptando el mando del regimiento de Querétaro; en 1841 se le concedió el grado de general de brigada. La cúspide de su carrera política la alcanzó en 1844, cuando desempeñó brevemente el cargo de gobernador y comandante militar del departamento de San Luis Potosí (Zayas, s. a., pp. 130-131).

\section{REPARTO DE LAS HACIENDAS Y VENTA DE RANCHOS (1861)}

A principios de 1861, apenas concluida la guerra de los Tres Años, José María Rincón les anunció a sus doce hijos que repartiría entre ellos las haciendas de Ciénega de Mata y le pidió a los ingenieros Manuel Plowes y Luis Díaz ${ }^{9}$ que formaran un plano general en el que se fijaron linderos, se determinó la extensión de todo el conjunto y se marcaron los ranchos

${ }^{8}$ Fondo de Protocolos Notariales, José María Calvillo, 1830, s. n., fs. 229-242, en Archivo Histórico del Estado de Aguascalientes (en adelante AHEA).

${ }^{9}$ Luis Díaz y Manuel Plowes, Plano general de la hacienda de Ciénega de Mata y sus anecsas, 1860-1861, documento sin clasificación, en AJMRG. 
del llano del Tecuán, lo que preludiaba su venta. Los autores de este plano eran ingenieros reputados, lo mejor que había en ese momento en México (Hernández, 2013; Sánchez, 1975, pp. 557-561).

Para valorar en sus justas dimensiones esta decisión es necesario recordar que desde mediados del siglo XVIII, gracias a Jovellanos (1979) y otros tratadistas, flotaba en el aire la idea de que las grandes concentraciones de tierras eran culpables de muchos de los males del país, como la miseria de las masas campesinas y el atraso de las prácticas agrícolas. Estas ideas ganaron en México carta de ciudadanía gracias a la labor de personajes como Francisco García Salinas, gobernador de Zacatecas y promotor en 1829 del establecimiento de un banco agrícola, que daba por sentados "los males que causa a la sociedad la acumulación de la propiedad territorial en pocas manos" (García, 1830). Por su parte, Jesús Terán, gobernador de Aguascalientes, afirmó en 1854 que era necesario remover los obstáculos que impedían la división de "esos inmensos desiertos que se llaman haciendas" (Covo, 1983, pp. 592-604). Sin embargo, ni la ley de desamortización de 1856 ni la Constitución de 1857 tradujeron esas ideas en medidas prácticas, pues el espíritu de la época estaba dividido entre la condena de los males derivados del latifundismo y la convicción de que era imposible alterar el derecho de propiedad, que se juzgaba consustancial a los individuos y por tanto anterior al pacto social (González, 1958; Silva, 1959). El único que intentó violentar ese derecho fue Esteban Ávila, gobernador de Aguascalientes, quien en 1861 promovió infructuosamente una ley agraria que imponía por la vía fiscal la necesidad de vender en fracciones las grandes haciendas; algunos han visto en esta medida un antecedente explícito de la reforma agraria (Reyes Heroles, 1982, vol. III, p. 618), e incluso un capítulo de la historia del pensamiento socialista en México (García, 1969, pp. 271-276), mientras que otros la conceptúan como una de esas "raras expresiones de radicalismo agrario, a las que tanto amor le tienen algunos intérpretes mexicanos del siglo XIX" (Hale, 1972, p. 180).

Lo que es un hecho es que las discusiones en el seno del Congreso Constituyente y la ley agraria del gobernador de Aguascalientes espantaron a los hacendados, quienes publicaron un panfleto exigiendo que sus derechos de propiedad fueran respetados (Llaguno, 1861, pp. 71-85). José María Rincón no figura entre los firmantes, pero con toda seguridad entendió que había llegado la hora de disolver su latifundio y repartir las haciendas entre sus hijos. Aunque legalmente el mayorazgo que había heredado ya no existía, en los hechos era dueño de una vasta fortuna que recordaba la vilipendiada época colonial, y en medio del caos reinante no era del todo remoto que el gobierno encontrara un pretexto para abalanzarse sobre ella, como se hizo con las haciendas de las familias Sánchez Navarro y Martínez del Río, a quienes el gobierno de Juárez acusó de infidencia 
(Bazant, 1983, pp. 575-577). Durante la guerra contra los franceses, algunos hacendados se disfrazaron de buenos patriotas y obtuvieron a cambio grandes recompensas (Salazar, 2011); Rincón Gallardo, quien tenía muchos hijos, jugó sus fichas en ambos lados del tablero, lo que al final de cuentas implicó que su familia evitara castigos y obtuviera premios.

Para calibrar en sus verdaderos alcances la decisión de disolver este latifundio conviene reparar en la extensión, el valor y la potencia productiva de las haciendas que lo integraban. Tomando como guía las escrituras relacionadas con la partición y adjudicación de bienes de José María Rincón, otorgadas en el verano de 1862 en la ciudad de León, podemos estimar que las haciendas y ranchos pertenecientes al latifundio alcanzaban una extensión de 360645 hectáreas, un enorme rectángulo distribuido entre los estados de Jalisco, Aguascalientes y Zacatecas (véanse mapas 1 y 2). Enclavado en el extremo noreste de la que sería después la "zona fundamental de los cereales" (Molina, 1978, p. 152), Ciénega de Mata era a mediados del siglo XIX uno de los latifundios más ricos del país. Aunque en términos de extensión muchas haciendas del norte lo superaban, tenía a su favor su emplazamiento en una región bien comunicada y más poblada, pero sobre todo el hecho de que en el transcurso de varios siglos había ido evolucionando hasta convertirse en un próspero emporio agrícola y ganadero.

En cuanto al valor de las tierras, ganados y mejoras, hay que considerar que Rincón les pidió a los peritos que asignaran valores "más bien bajos, porque los inventarios no son para vender, sino para repartirse entre mis hijos". De manera aproximada podemos calcular que el valor de las haciendas fue disminuido en 35\%, de manera que no valían 2200000 pesos, sino 3000 000, lo que en términos de la época era el equivalente de una fortuna impresionante (véase cuadro 1).

En Ciénega de Mata se combinaban la agricultura y la ganadería. Se cultivaba primordialmente maíz, trigo y frijol, aparte de una gran variedad de frutas y verduras en las huertas que había en casi todas las haciendas. El ganado menor de lana y pelo, cuya crianza había sido introducida en el siglo XVII, había ido ganando terreno hasta convertirse en uno de los giros más productivos del latifundio. En contrapartida, la cría de caballos y otras variedades de ganado mayor, que habían hecho la fama de Ciénega de Mata durante la segunda mitad del siglo XVIII (Serrera, 1977, pp. 313-315), había perdido importancia. Algunas haciendas eran predominantemente ganaderas, mientras que en otras los cultivos tenían la preferencia. En total, había 6976.4 ha beneficiadas con riego, cantidad que habla por sí sola de la potencia productiva del latifundio. Como punto de comparación podemos referir que en todo el estado de Aguascalientes había 699 fanegas de riego (2 516 ha), la tercera parte de las que había en Ciénega (Epstein, 1861) (véase cuadro 2). 

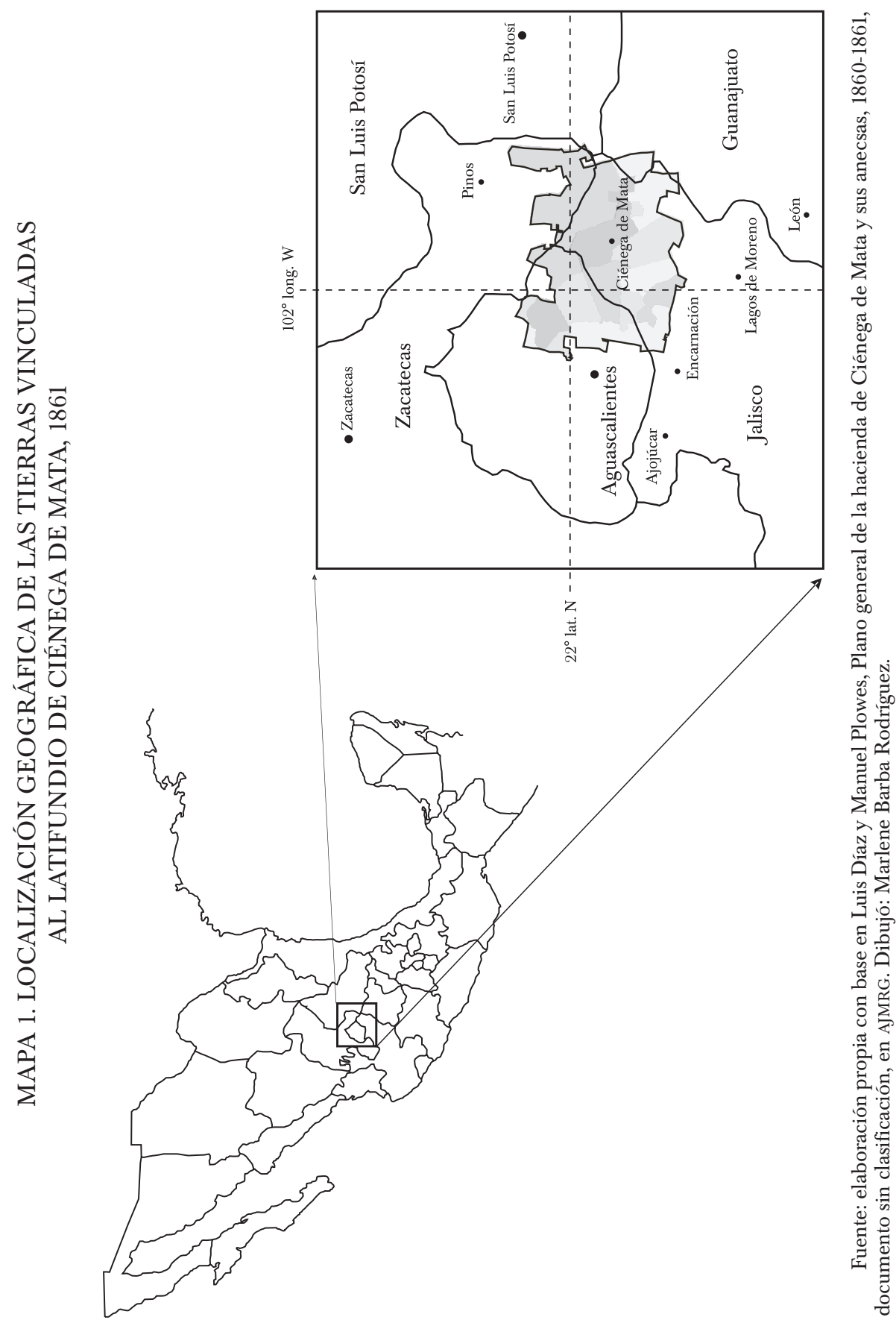


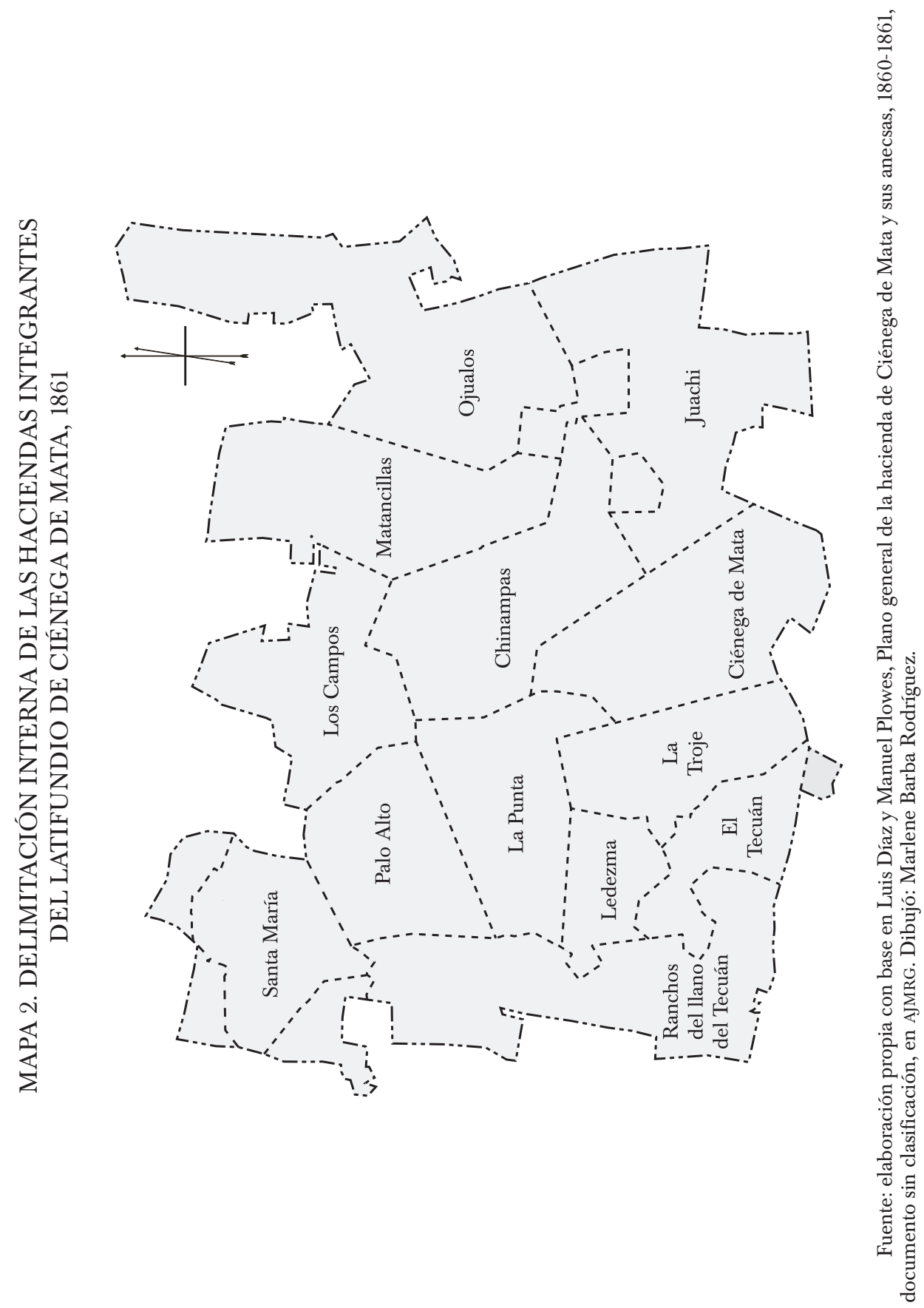




\section{CUADRO 1. EXTENSIÓN Y VALOR DE LA HACIENDA DE CIÉNEGA DE MATA Y SUS ANEXAS, 1861}

$\begin{array}{lrr}\text { Hacienda } & \text { Extensión (ha) } & \text { Valor (pesos) } \\ \text { Ojuelos } & & \\ \text { Juachi } & 47165.6 & 203248.12 \\ \text { Matancillas } & 37236.0 & 161200.70 \\ \text { Ciénega de Mata } & 32271.2 & 167140.00 \\ \text { Chinampas } & 31244.0 & 189004.29 \\ \text { La Punta } & 28333.6 & 142248.30 \\ \text { Palo Alto } & 24326.0 & 128479.20 \\ \text { Los Campos } & 21057.0 & 110336.35 \\ \text { La Troje } & 19559.6 & 144238.70 \\ \text { Santa María } & 19088.8 & 169747.74 \\ \text { El Puesto y El Tecuán } & 18061.6 & 129005.57 \\ \text { Ledesma } & 13182.4 & 148911.48 \\ \text { Encinillas } & 10230.0 & 148056.43 \\ \text { Jaltomate } & 4558.2 & 39880.00 \\ \text { Rancho de Anguillo (anexo a Chinampas) } & 4151.6 & 41208.24 \\ \text { Subtotal haciendas } & 3979.8 & 20165.00 \\ \text { Ranchos en el llano del Tecuán y haciendas } & 314445.4 & 1942870.12 \\ \text { Totales } & 46189.3 & 285448.96 \\ & 360645.4 & 2228319.08\end{array}$

Fuentes: Escrituras de partición y adjudicación de bienes de José María Rincón Gallardo: Ojuelos, Archivo de Notarías de León (en adelante ANL), José María Rodríguez y Borja, 1862, 142, 436-469; Juachi, ANL, José María Rodríguez y Borja, 1862, 139, 343-369; Matancillas, ANL, José María Rodríguez y Borja, 1862, 144, 507-537; Ciénega de Mata y su anexa La Presa, Agustín Arrieta, 1862, 88, 193-241; Chinampas y rancho del Sáuz, ANL, Agustín Arrieta, 1862, 94, 330384; La Punta, ANL, Agustín Arrieta, 1862, 96, 387-424; Palo Alto, ANL, Agustín Arrieta, 1862, 90, 245-288; Los Campos, ANL, José María Rodríguez y Borja, 1862, 141, 405-436; La Troje y molino de San Benito, AnL, José María Rodríguez y Borja, 1862, 145, 538-575; Santa María de Gallardo, ANL, Agustín Arrieta, 1862, 92, 304-315; El Puesto y El Tecuán, ANL, José María Rodríguez y Borja, 1862, 140, 370-404; Ledesma, ANL, José María Rodríguez y Borja, 1862, 144, 479-489; Encinillas, ANL, José María Rodríguez y Borja, 1862, 141, 405-436; Jaltomate, ANL, Agustín Arrieta, 1862, 90, 245-288; Rancho de Anguillo (anexo a la hacienda de Chinampas), ANL, Agustín Arrieta, 1862, 94, 330-384, y Luis Díaz y Manuel Plowes, Plano general de la hacienda de Ciénega de Mata y sus anecsas, 1860-1861, documento sin clasificación, en AJMRG. 


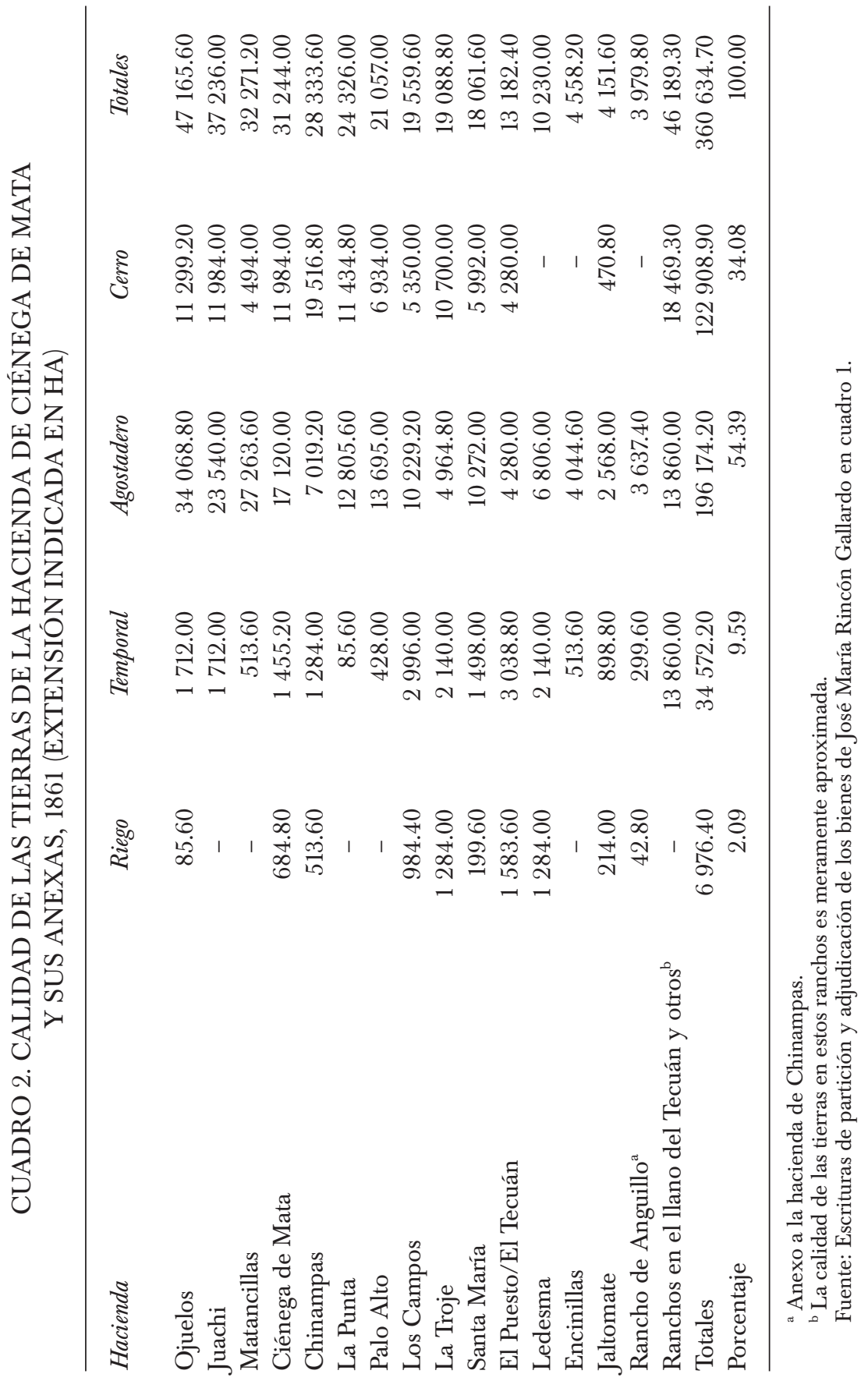


Al mismo tiempo que repartía las haciendas entre sus hijos, José María Rincón decidió que todos los ranchos formados en el llano del Tecuán y algunas haciendas fueran vendidos a sus antiguos arrendatarios. Los ranchos ocupaban una superficie aproximada de 46000 ha, que se convirtieron en propiedad de las familias que durante varias generaciones se habían empeñado en abrirlas al cultivo. Los arrendatarios tenían casi 30000 cabezas de ganado y pagaban a la casa una renta anual de más de 20000 pesos. ${ }^{10}$ La decisión de vender estos ranchos se ofrecía como la conclusión lógica de un proceso incubado a lo largo de toda la primera mitad del siglo XIX. La noticia se esparció como reguero de pólvora ${ }^{11}$ y es posible que en un principio los rancheros se hayan resistido a creer que fuera cierto lo que se decía, preguntándose, al igual que los vecinos de Cojumatlán, en la ribera del lago de Chapala (González, 1979, pp. 50-52), si no sería una treta de abogados destinada a arrebatarles sus ahorros. Ciénega parecía un latifundio inextinguible, al que ni el tiempo, ni las leyes, ni los cambios de régimen habían sido capaces de destruir. ¿Por qué se vendían ahora los ranchos? Pero los temores fueron apagándose poco a poco, conforme los rancheros iban a Aguascalientes o Lagos y regresaban con los títulos de propiedad en sus manos, convertidos en dueños y señores de la tierra que habían cultivado durante toda su vida.

La venta de ranchos en el llano del Tecuán constituye un episodio fundamental en el contexto de la historia regional de la tenencia de la tierra. La "notoria laboriosidad" y la "perfecta división de la propiedad" de las que habló A. González (1887), testigo de la época, refiriéndose al llano, tenían sin duda su origen en ese episodio. A la larga, más que un negocio, la venta de ranchos fue una especie de reforma agraria a escala regional promovida por el último dueño del latifundio de Ciénega de Mata, sólo que alentada por un particular y no por el Estado, como sucedería después. Es indudable que existen hilos de continuidad entre el fraccionamiento de las haciendas durante el siglo XIX, "por deudas, herencia o venta", y el agrarismo revolucionario (Escobar y Rangel, 2011, pp. 17, 21).

\section{Venta y fraccionamiento de haciendas durante la segunda mitad del siglo XIX}

José María Rincón les prohibió a sus hijos que vendieran o hipotecaran sus haciendas mientras él viviera, y les recomendó que tampoco lo hicieran después, "porque será en su perjuicio"; por el contrario, les pidió que se ocuparan personalmente de ellas para que aumentaran su fortuna y tuvie-

\footnotetext{
${ }^{10}$ AJMRG, caja 7, exp. 98, f. 1; caja 26, exp. 7, f. 98; caja 2, exp. 372, f. 2; caja 26, exp. 373, f. 1.
}

${ }^{11}$ El Porvenir, 13 de octubre de 1861. 
ran un porvenir digno de la "esmerada educación" que les había dado. ${ }^{12}$ Aunque las circunstancias volvían imperiosa la disolución del latifundio familiar, su último propietario soñaba con que en el futuro todas las haciendas seguirían perteneciendo a sus herederos. Sin embargo, los nuevos equilibrios resultaron frágiles, los tiempos que corrían eran difíciles y los hijos de Rincón mostraron un apego desigual a las labores del campo, lo que propició que en el curso de unas cuantas décadas varias haciendas fueran vendidas y otras vieran sustancialmente disminuida su superficie original, lo que por su lado fue un nuevo aliciente del proceso de subdivisión de la gran propiedad que se experimentó en la región.

En la hacienda de Ledesma se vendieron 18 fracciones entre 1874 y 1884, lo que redujo a la tercera parte su superficie original. ${ }^{13}$ En Ojuelos, el propio José María Rincón le propuso al gobierno del estado de Jalisco que erigiera una nueva cabecera municipal con el propósito de "mejorar la condición actual de sus arrendatarios a la de propietarios" (Serna, 1981, anexo s. p., y 1984, p. 34). Las autoridades aceptaron la propuesta y se vendieron 9000 ha entre los medieros y arrendatarios de la hacienda, equivalentes a la quinta parte de su superficie. La hacienda de Los Campos se le vendió a Manuel Jacinto Guerra y la de Jaltomate a la señora Marta Aldana de Camarena. Los hijos y nietos de José María Rincón conservaban a fines del siglo 180000 ha, la mitad de lo que medía el latifundio en el momento de su partición. Las haciendas y ranchos que tenían en el cantón de Lagos en 1880 alcanzaban un valor fiscal de 387000 pesos, equivalente a 25\% del valor de la propiedad rústica, y Ciénega de Mata era la hacienda más extensa del cantón, pero la familia Rincón Gallardo ya no tenía, ni de lejos, el peso que tenía a mediados de siglo. ${ }^{14} \mathrm{Al}$ lado de la vieja aristocracia latifundista emergió una nueva clase de hombres de negocios exitosos, porfiristas que habían coronado su carrera comprándose una gran hacienda (Gómez, 2000, pp. 402-403).

\section{Revolución}

Y luego vino la revolución de 1910 con todas sus secuelas, entre otras, la ley del 6 de enero de 1915, que establecía la expropiación de las haciendas como un mecanismo idóneo para restituir a los pueblos y comunidades las tierras de las que habían sido despojados (Escobar y Rangel, 2011, p. 25). "Pulsando cuidadosamente" la inconformidad derivada del hecho de que

\footnotetext{
${ }^{12}$ Archivo de Notarías de León, José María Rodríguez y Borja, 1863, pp. 136, 313-314.

${ }^{13}$ Archivo del Registro Público de la Propiedad de Lagos de Moreno, libros 1 y 2.

${ }^{14}$ Boletín de la Sociedad Agrícola Mexicana, t. II, núm. 5, 9 de octubre de 1880, p. 99.
} 
la tierra estaba acaparada por un puñado de grandes hacendados, "los gobiernos posrevolucionarios trazaron políticas encaminadas a acabar con la desigualdad agraria y a conducir a la sociedad por el camino de lo que entonces se percibía como progreso" (Aboites, 2002, p. 123). En el marco de ese programa, la revolución debilitó severamente y en muchos casos destruyó por completo el "viejo orden agrario" y a la oligarquía terrateniente que lo sostenía, permitiendo "la transición a nuevas formas políticas" de dominación (Knight, 2013, pp. 15, 51-52). El arma usada para ello fue el ejido, the Mexican way out según el título del libro de un estudioso estadunidense, la cuadratura del círculo en un país pobre, eminentemente rural y portador de una historia muy densa; en forma por demás significativa, cuando este trabajo se publicó en México se añadió un pequeño énfasis al título y se propuso que el ejido era en realidad la única salida disponible. ${ }^{15}$ En Aguascalientes, la construcción de la gigantesca presa Calles y la habilitación del primer distrito de riego que hubo en el país, con independencia de sus resultados en el ámbito productivo, implicó la destrucción de muchas haciendas y propició "la transición" de un sistema oligárquico a otro de signo clientelar (Hurtado, 2004, p. 15; Rojas, 1980; Ruvalcaba, 2016).

Uno de los problemas de la reforma agraria consistió en que los gobiernos emanados de la revolución actuaron a partir de un supuesto muy discutible, según el cual en todo el país había sucedido lo mismo que en Morelos, en donde las grandes haciendas y la industria azucarera prosperaron a costillas de los pueblos, que entre 1876 y 1910 fueron cercados, despojados y en algunos casos aniquilados. Como dice Womack (1969, pp. 45-48), "desposeídos y en la miseria, muchos campesinos comenzaron a trabajar como aparceros las peores tierras de las haciendas"; al mismo tiempo, las grandes fincas de ese pequeño estado se convirtieron en "las más modernas de México".

Esta afirmación es válida para los estados en los que había una fuerte presencia indígena, pero en otras regiones la historia de la propiedad de la tierra se escribió de manera diferente. En el Bajío no se observa durante el porfiriato una tendencia a la "concentración de la tenencia de la tierra" (Brading, 1988, p. 345), ni en los Altos de Jalisco, en donde las haciendas de Santa Ana Apacueco y Cuisillos fueron divididas desde fines del siglo XVIII en 150 fracciones, que a la larga acabaron siendo propiedad de sus arrendatarios (Bazant, 1982, pp. 33-41). Mucho menos en Aguascalientes, el sur de Zacatecas y el norte de Jalisco, donde estaban enclavadas las ha-

${ }^{15}$ The ejido: Mexico's way out es el título original del libro de Eyler Simpson, publicado por la Universidad de Carolina del Norte en 1937, impreso en México en 1952 como El ejido: única salida de México. Durante su estancia en nuestro país, Simpson y su esposa fueron objeto de diversos galanteos por parte de muchos funcionarios del gobierno cardenista, como recuerda uno de ellos (Silva, 1993, p. 86). 
ciendas de Ciénega de Mata. Como tal, el latifundio se desintegró en 1861 y sus haciendas experimentaron durante las últimas décadas del siglo XIX una tendencia incontenible a la fragmentación. En el llano del Tecuán y en casi todas las haciendas había cientos de ranchos que se habían subdividido entre los descendientes de sus propietarios originales. Los papeles del Registro Público de la Propiedad y los protocolos de los escribanos documentan sin lugar a dudas que la tendencia dominante no era hacia la concentración de la propiedad y la formación de haciendas inmensas, como afirmó Andrés Molina Enríquez (1978, pp. 166-167), quien pretendía que la gran propiedad compensaba "por extensión" sus debilidades internas. La tendencia documentable es exactamente la contraria y apunta hacia el fortalecimiento de las clases medias propietarias en el campo, como lo demuestra el ejemplo de la región de Aguascalientes (Gómez, 2000). Incluso en el gran estado de Michoacán, al lado de Naranja y otros pueblos que vieron violentados sus derechos (Friedrich, 1984), hay regiones en las que se ha identificado la aparición de verdaderas "sociedades rancheras" (Barragán, 1994). En la rica región de Papantla (Veracruz), marcada por la producción de vainilla, la ofensiva liberal contra la propiedad comunal de las tierras no fue una imposición del Estado, sino que se alentó "desde abajo", pues fueron los habitantes de pueblo quienes imprimieron su "ímpetu" y su carácter "pacífico" al proceso de privatización (Kourí, 2013, pp. 17-19, 197-215). En suma, el panorama es mucho más complejo de lo que pensaban los defensores de la "leyenda negra" de la hacienda (Escobar y Gutiérrez, 2009, pp. 40-42).

El movimiento maderista no trastornó seriamente la vida económica de la región, aunque muchas haciendas y minas fueron asaltadas por revolucionarios. Manuel Rincón Gallardo y José Pérez Castro encabezaron una partida de revolucionarios que merodeó la ciudad de Aguascalientes, pero los apellidos del primero inspiraban cierta tranquilidad, pues se creía que eran garantía de que no permitiría los excesos que se veían en casi todas partes. ${ }^{16}$ A fines de mayo de 1911, entraron sin resistencia en la ciudad de Aguascalientes, que había sido abandonada previamente por el gobernador.

Pero estos escarceos fueron apenas el preámbulo del verdadero vendaval que azotó la región en 1914 de la mano de los ejércitos constitucionalistas, que en el contexto de la ofensiva contra el régimen de Huerta tomaron muchas haciendas y poblaciones de la región; fue entonces cuando los grandes propietarios fueron vistos como "enemigos de la causa", tomándose contra ellos diversas medidas, incluida su eliminación física. Algunos huyeron para salvar la vida, pero los que habían apoyado a Huerta (y

${ }^{16}$ El Clarín, 13 de mayo de 1911, en AHEA. 
en Lagos y Aguascalientes la mayoría lo hicieron) resultaron "hombres marcados [...] y no hubo arrepentimiento o retracción de su parte que pudiera borrar el estigma” (Knight, 1996, vol. II, p. 767). Si Villa no podía hacer la paz con los Terrazas ni Zapata con los Pimentel, tampoco podía hacerla Carranza con los Rincón Gallardo. En Ciénega de Mata las tropas villistas tuvieron cuartel y según la tradición familiar usaron las imágenes de bulto de los santos para practicar tiro al blanco. En la época de la ocupación villista, y luego bajo el carrancismo, muchas haciendas fueron intervenidas, "como se les llamaba a las confiscaciones de los revolucionarios". Aunque ello no implicó la "ruina total" de las fincas, sus resultados fueron desastrosos (Katz, 1998, t. 2, p. 26; 1994, p. 253). Ciénega de Mata, lo mismo que muchas otras haciendas de la región, fue intervenida durante algún tiempo y luego devuelta a sus dueños, sin que nadie se hiciera cargo de los daños y las pérdidas. ${ }^{17} \mathrm{Al}$ mismo tiempo, comenzaron los amagos de la reforma agraria. Dentro de las haciendas que habían formado el latifundio no había comunidades indígenas ni pueblos a los que hubiera que restituir tierras, pero la nueva legislación consideró a los peones de las haciendas "sujetos de derecho agrario" a los que se podía "dotar" de tierras (Fujigaki, 2006, p. 68). En todo el país las cabeceras de las haciendas y otras rancherías, organizadas por los agentes del gobierno, empezaron a pedir dotaciones. Cobró forma el agrarismo, que era un intento de trasladar masivamente la tierra de manos de los hacendados a las de los campesinos, modificando con ello la estructura productiva del país, pero todo "mediado por la acumulación del poder político". A partir de entonces, los propietarios tuvieron que librar una guerra en dos frentes: contra los campesinos que exigían tierra y contra el Estado que quería "modernizar" y usaba a las organizaciones campesinas como ariete (Schettino, 2007, pp. 208-209).

Aunque ello no significa que el agrarismo haya sido abrazado por los campesinos de todo el país como una panacea, pues al lado de "lealtades feroces" también suscitó "fuertes recelos" e incluso "una abierta oposición"; en cualquier caso, el exterminio de la gran propiedad y la reconstitución del campesinado mexicano eran las dos caras de un proceso "destinado a ser desordenado y violento". El agrarismo, entendido como "la dimensión política de la reforma agraria", fue un fenómeno mucho más complejo y lleno de matices de lo que habitualmente se concede, pues hubo comunidades "tranquilas durante la revolución" que enseguida lo abrazaron con entusiasmo, y otras que se mostraron refractarias o de plano lo evadieron; en muchas ocasiones fue un recurso que usó el Estado para propiciar la centralización, pero en otras la iniciativa procedió de los cau-

\footnotetext{
${ }^{17}$ Informe del estado con relación de los bienes intervenidos y desintervenidos, Jalisco, Fondo Gobernación-Periodo Revolucionario, caja 222, exp. 52, 1917, en AGN.
} 
dillos regionales que instrumentaban la reforma "para sostener intereses locales". Incluso se dio el caso de terratenientes que por razones tácticas fomentaron "una reforma cosmética" dentro de sus dominios, pero que acabaron sufriendo verdaderas "amputaciones" (Knight, 2013, pp. 42-47). En Aguascalientes, a partir de 1917 los hacendados fraccionaron voluntariamente muchas grandes propiedades, lo que fue tanto como anticiparse a la ofensiva agrarista, aunque no se ha logrado determinar qué tanto éxito tuvieron (Rojas, 1980, pp. 116-124).

\section{En busca de una nueva vocación productiva}

Ciénega de Mata, la hacienda madre del latifundio, fue a parar a manos de Eduardo Rincón Gallardo, el menor de los hijos de José María Rincón. En 1903, cuando murió, lo heredaron su esposa, María Refugio Romero de Terreros, y sus hijos Carlos, Carmen, María y Alfonso. En 1939 este último compró a sus hermanos las participaciones que tenían en la sucesión testamentaria de su madre y quedó como dueño único de la hacienda. Para trabajarla, formó una sociedad con sus hijos Eduardo, Jaime y Alfonso Rincón Gallardo y Mier.

La hacienda había sido afectada por la reforma agraria desde 1927, pues un decreto dispuso que se dotara de ejidos (1 $162.6 \mathrm{ha}$ ) al poblado de Matanzas. Sin embargo, fue mucho más ruinosa la dotación de 2000 hectáreas que se hizo en 1936 a favor del poblado de Ciénega de Mata: 300 hectáreas de riego, 528 de temporal o laborables y 1172 de agostadero cerril. ${ }^{18}$ A ello se añadió la dotación que se hizo a favor de la comunidad de La Presa en agosto de 1937: 292 ha de riego y 609 de agostadero. ${ }^{19}$ En todos los casos el argumento que justificaba la expropiación era el mismo: los poblados beneficiados se hallaban dentro de las tierras de la hacienda y sus habitantes tenían la agricultura por única ocupación, pero carecían de las tierras "que les son indispensables para satisfacer sus necesidades". Estas primeras expropiaciones le quitaron a la hacienda casi todas las tierras de riego que tenía y de un plumazo acabaron con su actividad más rentable, que era el cultivo de cereales y chilares en estas tierras de labor (Rincón, 1989, pp. 1-2). Los vecinos de La Presa lucharon durante años para que se les concediera más agua con la cual regar las parcelas de su ejido. A la postre se resolvió en su contra, pero porque ya no quedaba agua en Ciénega de Mata, pues "todo el volumen que en conjunto proporcionan las

\footnotetext{
${ }^{18}$ Diario Oficial de la Federación (en adelante DOF), 14 de septiembre de 1936.

${ }^{19} \mathrm{DOF}, 16$ de junio de 1939 .
} 
presas de San Juan y Las Cebolletas, así como el manantial denominado Charco Redondo, corresponde al propio ejido de La Presa". ${ }^{20}$

En marzo de 1939, cuando Alfonso Rincón Gallardo y sus hijos se convirtieron en dueños de Ciénega de Mata, la encontraron en situación ruinosa, sin tierras de labranza y apenas 500 caballos y 17 bueyes. Nada que ver con los inventarios de 1861, en los que las cabezas de ganado se contaban por decenas de miles. Se debían además dos años de contribuciones prediales, diversas cantidades por concepto de salarios no pagados y "otros picos sueltos". La casa grande de la hacienda sufrió muchos daños durante la ocupación villista, pero luego fue restaurada y en 1939 se encontró en buen estado. El principal activo de la hacienda eran los agostaderos, unas planicies resecas situadas a más de 2200 metros de altura, 26000 ha en total. También conservaba una huerta en la que se cultivaban hortalizas, pero los rancheros del Tepetatillo le negaban el agua necesaria para los riegos, que era provista por la presa La Duquesa. Había un "enconado litigio" entre los Rincón Gallardo y esos rancheros. El joven abogado Jaime Rincón trató de resolver el problema, pero encontró el camino lleno de toda clase de obstáculos y, además, la previsible debilidad del gobierno del general Cárdenas por los pequeños propietarios. Finalmente se logró un acuerdo privado en términos del cual se admitió el derecho que tenían los Rincón Gallardo a esas aguas, pero limitado al riego de la huerta (Rincón, 1989, pp. 1, 3-4).

Vivía en la región Pierre Salabert Abancens, un joven francés originario de Oloron-Sainte Marie, una comuna del departamento de los Pirineos Atlánticos. Después de pelear como soldado en la gran guerra emigró a México. En la capital del país conoció a la familia Rincón Gallardo, que lo contrató como administrador de Ciénega de Mata. Valido probablemente del conocimiento que tenía de ciertas tradiciones artesanales, empezó a hacer un queso al que llamó Olorón, en recuerdo de su tierra natal. Su negocio prosperó, pues los quesos se vendían bien en Aguascalientes, Lagos de Moreno y León. Con sus ahorros compró el rancho La Troje, en tierras del antiguo latifundio, un carro para distribuir sus productos y una descremadora. Además, era "un hombre trabajador y honradísimo" y sus quesos eran magníficos. Conviene advertir que el antiguo administrador de la hacienda, enriquecido gracias a su fábrica de quesos, se convirtió en un aliado estratégico de Alfonso Rincón Gallardo y sus hijos, pues les financiaba los gastos de la hacienda y la compra de ganado (Rincón, 1989, pp. 2-3).

Fue en esas circunstancias como Ciénega de Mata encontró su vocación productiva en el siglo XX. Gracias a los consejos de varios ganaderos exitosos en la región se tomaron decisiones acertadas. En el frente político

${ }^{20}$ DOF, 13 de mayo de 1953, pp. 14-15. 
destaca la obtención en 1942, ya durante el sexenio de Ávila Camacho, que como se sabe moderó la política agrarista de su antecesor, de un certificado de inafectabilidad que amparaba 26354 ha de terrenos de agostadero durante el término de 25 años. ${ }^{21}$ Estos certificados se otorgaban a "fincas" enclavadas en regiones donde "no hay problema agrario"; su propósito era estabilizar la propiedad de la tierra y son una expresión del viraje de la política hacia el campo, pero en el fondo ilustran una tensión no resuelta, pues por un lado el gobierno necesitaba el apoyo político de los agraristas, pero por el otro quería "reconstruir la economía rural", fomentar las inversiones productivas y asegurar los derechos de los propietarios (Aboites, 2002, p. 124; Warman, 2001, p. 73). Basados en la cantidad de certificados de inafectabilidad concedidos, algunos autores pretenden que su verdadero resultado fue reconstituir el latifundio "sobre bases firmes" (Gutelman, 1974, p. 117; Semo, 1988), pero la historiografía seria ha demostrado que esta tesis es insostenible, a pesar de lo cual cuenta todavía con numerosos epígonos.

En realidad, esos certificados funcionaban como espadas de Damocles, pues en cualquier momento podía determinarse que había resurgido un problema agrario y amenazarse a las fincas inafectables con nuevas expropiaciones. De hecho, en 1948 la superficie de Ciénega de Mata fue disminuida en 2408 ha (90 de riego y 2318 de agostadero), con las cuales se atendió favorablemente la solicitud de ampliación de ejido presentada por los pobladores de Primo Verdad (nombre con el que se rebautizó el casco de la hacienda). Con esta expropiación la superficie inafectable de la hacienda quedó reducida a 23945 hectáreas, en sí nada despreciable, tres cuartas partes de la que tenía en 1861, pero hay que tener en cuenta que se habían perdido en cuatro dotaciones ejidales las mejores tierras y los derechos sobre agua, debido a lo cual quedó fracturada en forma irremediable su antigua vocación productiva. ${ }^{22}$ Considerando la intensidad que alcanzó la reforma agraria, así como el hecho de que "el reparto agrario fue uno de los instrumentos políticos más eficaces para el fortalecimiento gubernamental" (Aboites, 2002, p. 125), no fue poco lo que se salvó. El propio Jaime Rincón (1989, pp. 4-5) considera que la obtención de estas concesiones de inafectabilidad constituyó una importante victoria.

Hacia 1947 los jóvenes Rincón Gallardo llegaron a un acuerdo sobre la mejor manera de administrar su negocio. Alfonso se radicó de manera permanente en Ciénega y asumió in situ la dirección de las operaciones productivas, mientras que Jaime se ocupó de la venta de ganado en el rastro de la ciudad de México y del seguimiento en esa capital de los

${ }^{21}$ DOF, 20 de junio de 1942, pp. 11-13.

${ }^{22}$ DOF, 9 de abril de 1948, pp. 2-3 y 24 de febrero de 1951, pp. 11-13. 
continuos problemas agrarios, para lo cual le era muy útil su formación de abogado. En 1956, a la muerte de su padre, la negociación fue dividida en tres partes iguales (Rincón, 1989, p. 5).

La gestión de Alfonso Rincón Gallardo y Mier fue muy atinada, pues logró expandir con sentido productivo el negocio de la engorda de novillos, que consistía en comprar toretes corrientes en los cañones de Juchipila, luego descornarlos, castrarlos y vacunarlos, y finalmente soltarlos en las mesas altas para que gozaran una vida tranquila. El resultado que se obtenía con esos nobles animales, sin más gasto que el pastoreo en el potrero, era que ganaban 50 kilogramos de peso en un año y mejoraba mucho la calidad de su carne, lo que permitía venderlos en la ciudad de México con un buen margen de utilidad (Rincón, 1989, pp. 6-7).

Aparte de los problemas derivados de la reforma agraria tuvieron que sortearse otros, como un peligroso brote de fiebre aftosa que se dio en febrero de 1949. Fue necesario sacrificar más de 500 cabezas, para lo cual se contó con la intervención de técnicos estadunidenses (Rincón, 1989, p. 7). Bajo presión del gobierno de Estados Unidos, se elaboró un programa tendente a su erradicación en México, que fue popularmente conocido como rifle sanitario. Sus autores eran veterinarios y ganaderos de Estados Unidos, en donde el método ya había probado su eficacia. "Pero México no es Texas y la res no es filete, sino un elemento fundamental de la economía agrícola", pues cada propietario "tiene sus vacas y su yunta de bueyes para trabajar la tierra”, por lo que liquidar sus animales significaba destruir la base misma de su pequeño negocio. Luego de liquidar cerca de 500000 cabezas de ganado, dislocando con ello la economía campesina y provocando escasez de leche, carne y cereales, el gobierno modificó su estrategia y optó por la vacuna. Para muchos, el remedio del rifle sanitario resultó peor que la enfermedad (Meyer, 1983, pp. 93-95).

Con esa misma receta se combatió en 1961 un brote de encefalitis equina y se erradicó en 1972 al gusano barrenador. Las tres campañas, en opinión de Jaime Rincón, eran buenos ejemplos de los sensacionales resultados que se obtenían cuando la intervención del gobierno era oportuna y bien informada, aunque no ignoraba que la participación de los estadunidenses había tenido un carácter interesado (Rincón, 1989, pp. 7-8).

\section{El final de la hacienda}

En el curso de la década de 1950 los hermanos Rincón Gallardo cambiaron gradualmente el giro de su negocio, pues abandonaron la producción de leche y se concentraron en la de carne. Siguieron en ello el consejo que les dio un ganadero de Durango, a quien le compraron un lote de vacas y 
dos toros de la raza Aberdeen Angus. Con ese mismo propósito de cruza se importaron de Canadá dos vacas y un toro. Por su parte, la caballada fue mejorada con el uso de sementales de pura sangre, de carreras, así como un semental de cuarto de milla procedente del famoso King Ranch, en Texas (Rincón, 1989, pp. 8-9).

El aprovechamiento ganadero fue mejorado gracias a la obtención, en 1972, de un permiso de exportación a Estados Unidos de los becerros criados en Ciénega de Mata, en virtud de que fueron declarados libres de la garrapata transmisora de la piroplasmosis (Rincón, 1989, p. 12). En otras regiones del país se dio también durante estos años una acelerada expansión de la ganadería, que tenía como uno de sus motores "la creciente importancia del mercado estadounidense" (Aboites, 2002, p. 131).

Además, aprovechando la considerable cantidad de terreno disponible en las mesas, se reintrodujo la cría de ganado menor. Se llegó a contar con un hato de 3000 cabezas, poco más de la mitad de las que había en 1861. Este negocio tuvo que darse por terminado en 1965, cuando se acercaba la fecha en la que caducaría la resolución sobre inafectabilidad ganadera de 1942 y se sabía que el gobierno del presidente Díaz Ordaz tenía la intención de no prorrogar ese tipo de certificados. Los hermanos Rincón Gallardo entendieron en su momento algo que no siempre tiene presente la historiografía, el hecho de que "el presidente Díaz Ordaz se propuso culminar con el reparto agrario y llevó a cabo la mayor dotación de la historia en cuanto a extensión": 24700000 ha, 32\% más de las repartidas por Cárdenas (Fujigaki, 2006, cuadro 2.1; Warman, 2001, p. 70). En estas circunstancias, se tomó entonces una decisión dolorosa pero muy sensata, pedirle al gobierno "que nos reconociera la pequeña propiedad ganadera inafectable y dispusiera de los terrenos sobrantes". O sea, liquidar de una vez por todas la hacienda, o lo que quedaba de ella. Las gestiones culminaron con una resolución presidencial fechada el 20 de octubre de 1965, mediante la cual se concedieron a los vecinos de Chinampas, en calidad de segunda ampliación de su ejido, 10194 ha de agostadero, "que se tomarán íntegramente del predio denominado Ciénega de Mata". Estas tierras fueron puestas voluntariamente a disposición del Departamento de Asuntos Agrarios y Colonización por los hermanos Rincón Gallardo en términos de una negociación cuya contraparte consistió en que se reconocieran como inafectables los tres predios que se formaron con las 12226 ha restantes, a lo que quedó reducida la superficie de la antigua hacienda. ${ }^{23}$

Al mismo tiempo, los hermanos Rincón Gallardo formalizaron ante notario la división de sus agostaderos en las tres fracciones previstas por la ley, a fin de que cada una de ellas y por separado, en su carácter de

${ }^{23}$ DOF, 9 de diciembre de 1965, pp. 19-20, y Rincón (1989, pp. 10-11). 
pequeñas propiedades, fuera beneficiada por un acuerdo presidencial de inafectabilidad ganadera permanente "para los efectos de dotación y ampliación ejidales o de creación de nuevos centros de población agrícolas". La adjudicación fue hecha según los resultados de un sorteo que hicieron entre ellos, arbitrado por su madre. La fracción A (3 677 ha) le tocó a Eduardo, la fracción B (4 462 ha) a Jaime y la C (4 087 ha) a Alfonso. La superficie de las fracciones resultó desigual, pero se procuró que fueran iguales en valor. ${ }^{24}$ Esta división dio origen a tres negocios completamente independientes, tal como se conservan hasta la fecha.

Sin embargo, con todo y los acuerdos de inafectabilidad permanente de que gozaban los ranchos, hubo todavía una última afectación, favorable a un grupo de campesinos radicados en La Presa, que le solicitaron al gobernador de Jalisco la ampliación de su ejido. Se les concedieron 347.2 ha de tierras de agostadero de mala calidad, con carácter de primera ampliación definitiva de ejido. ${ }^{25}$ La hacienda de Ciénega de Mata sufrió en total seis afectaciones a lo largo del siglo Xx, y perdió más de la mitad de las tierras que tenía en 1861 (véase cuadro 3).

\section{Hacia el siglo XXI}

En enero de 1992, en el contexto de la política modernizadora del presidente Salinas de Gortari, se modificó el artículo 27 de la Constitución, cuyo texto se había considerado intocable durante muchos años y era objeto de veneración entre los partidarios del reparto agrario. En su parte medular la reforma reconocía "la personalidad jurídica de los núcleos de población ejidales y comunales" y abría una ventana para que los ejidatarios y comuneros adoptaran "las condiciones que más les convengan en el aprovechamiento de sus recursos productivos", por lo que podían "asociarse entre sí, con el Estado o con terceros", otorgando "el uso de sus tierras", e incluso venderlas. ${ }^{26}$

Desde la izquierda más dogmática, esta reforma fue conceptuada como una contrarreforma que traicionaba el espíritu original del artículo 27 de la Constitución y creaba las condiciones en las que prosperaría el neolatifundismo (Durand, 1993). Arturo Warman (1996), uno de los principales promotores de la reforma, sostiene que esta "terminó con el reparto agrario", es decir, con la obligación del Estado de "dotar con tierras y

${ }^{24}$ DOF, 30 de noviembre de 1970, pp. 33-34; Rincón (1989, p. 11). Los acuerdos sobre inafectabilidad de las fracciones A y C fueron publicados en el $D O F, 28$ de julio de 1970.

${ }_{25}$ DOF, 23 de junio de 1989 .

${ }^{26}$ DOF, 6 de enero de 1992. 


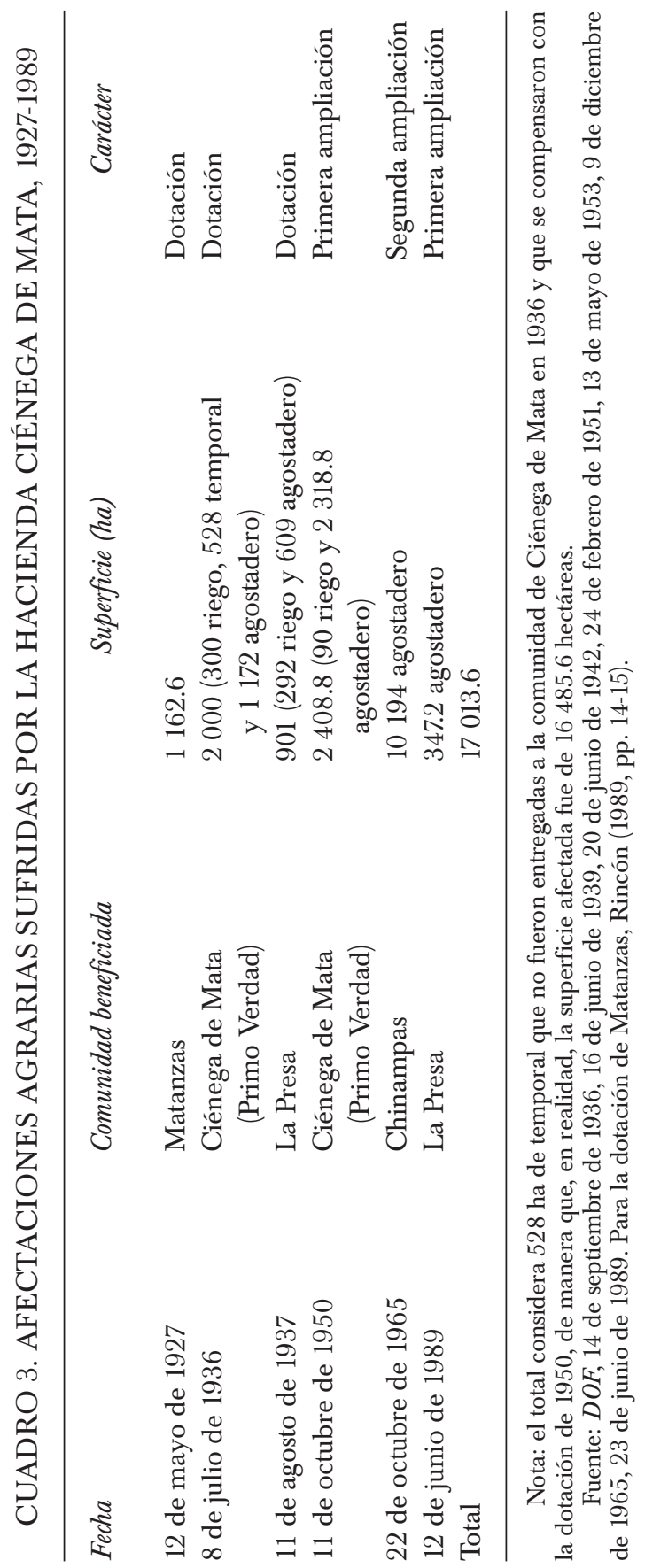


aguas suficientes" a los campesinos que las necesitaran o las solicitaran. Entre 1917 y 1992 "se dotó a treinta mil ejidos y comunidades con un poco más de cien millones de hectáreas que representan más de la mitad del territorio nacional", lo cual quiere decir que la ley se cumplió "mientras hubo posibilidad", pero en 1992 ya era imposible para el Estado cumplir su "obligación [...] de dotar con diez hectáreas de tierra a cada solicitante [...] sobre todo frente a una población que creció casi seis veces desde el inicio del reparto agrario". En pocas palabras, la demografía había puesto fin al reparto: "los ejidatarios y sus familias, quince millones de mexicanos, son más numerosos que la población total del país cuando se inició el reparto". En cuanto a las críticas recibidas por la reforma, Warman (1996) hacía notar que estaban centradas en su intención privatizadora, concepto que tiene una enorme carga ideológica y evocaba un pasado falso e idílico en el que "lo privado era malo y lo colectivo bueno, lo particular era funesto y lo deseable era estatal, corporativo y burocrático".

Los propósitos de la reforma de 1992 eran muy ambiciosos: fomentar la productividad, elevar el ingreso de los campesinos, alentar la participación del capital privado en el campo, convertir a los ejidatarios en dueños de sus parcelas y revertir la tendencia al minifundismo. Se ponía fin al reparto agrario y a esa larga época en la cual el Estado había tutelado a los ejidatarios (Leyva, 1992, p. 295; Valdez, 1993, p. 60 y ss.). Una de sus implicaciones más importantes fue la creación del Programa de Certificación de Derechos Ejidales y Titulación de Solares Urbanos (ProcedE), cuya finalidad era dar certeza y seguridad jurídica en la tenencia de la tierra a los ejidatarios mediante la entrega de certificados y títulos de propiedad (Olivera, 2005). Hasta entonces, la posesión precaria que tenían los ejidatarios se traducía en una precariedad productiva, pues los ejidatarios no invertían en el mejoramiento de sus parcelas. La titulación hecha al amparo del PROCEDE daba por fin certeza a los ejidatarios, que de esta manera tenían incentivos para mejorar sus cultivos (Warman, 1996, p. 8).

\section{Conclusiones}

Las estrategias usadas por los Rincón Gallardo son típicas de las familias que conformaban la elite económica y social de Nueva España: acapararon tierras, planearon las carreras de sus hijos para que desempeñaran cargos políticos y religiosos, utilizaron a sus hijas para establecer alianzas con otras familias importantes, consiguieron títulos militares y al final de la época colonial el de marqueses de Guadalupe.

Aunque muchas de estas prácticas pueden calificarse de señoriales, debe subrayarse que la familia siempre tuvo una preocupación por la ex- 
plotación racional de sus fincas y la obtención de ganancias (Nickel, 1988, p. 53), como lo prueba la Memoria redactada por José Rincón en 1703 (Gómez y Delgado, 2005). Los administradores del latifundio supieron sacar ventaja de su posición geográfica, ubicado entre los grandes centros mineros del Norte y la red de ciudades del Bajío novohispano. Aunque es evidente cierta tendencia a la autosuficiencia, estamos lejos de la interpretación de los latifundios como unidades de producción aisladas en medio de mercados fragmentados, pues Ciénega de Mata estaba firmemente integrado a los distintos mercados regionales y su radio de comercialización abarcaba desde Zacatecas hasta Puebla (Moreno, 1998, pp. 80-84; Sempat, 1998, pp. 58-60).

En el contexto de las estrategias empleadas por los Rincón Gallardo para conservar sus privilegios, la fundación de un mayorazgo en el siglo XVII tuvo un carácter fundamental, pues permitió que la familia se mantuviera como una de las más ricas e importantes de México hasta fines del porfiriato. Imperfecto en sus orígenes, este vínculo fue la piedra angular del estatus social y la influencia de los Rincón Gallardo. Esta constatación pone en entredicho la tesis según la cual la fundación de mayorazgos respondía sólo a las ambiciones aristocráticas de los grandes hacendados, sin que desempeñaran ninguna función económica (Mörner, 1975, p. 25).

Contra viento y marea, el latifundio de Ciénega de Mata se mantuvo intacto hasta 1861, cuando las haciendas fueron repartidas entre los hijos de José María Rincón Gallardo y se vendieron más de 100 ranchos en el llano del Tecuán a sus antiguos arrendatarios. Esta fue una medida muy inteligente que le permitió a la familia mantener un gran peso en la vida económica, social e incluso política del país, pues Pedro Rincón Gallardo, uno de los hijos de José María, después de hacer la guerra contra los franceses del lado de Juárez, resultó presidente del Ayuntamiento de la ciudad de México, diputado, senador y, en suma, un hombre "notable por su lealtad a los principios liberales" (Paz, 1988, pp. 167-168; Rodríguez, 2011, pp. 60-63). Por su parte, Rodrigo Rincón fue gobernador del estado de Aguascalientes y su hijo Francisco se casó nada menos que con Luz Díaz, hija del presidente de la república. La pareja compró en 1900 la hacienda de Santa María de Gallardo, que había formado parte del latifundio familiar, a la que algunos consideran "una de las más ricas del país" (Tello, 1994, p. 119). Cuando estalló la revolución, los Rincón Gallardo estaban inequívocamente ligados al antiguo régimen, con el que por supuesto tenían que caer.

La reforma agraria redujo la extensión de Ciénega de Mata a poco más de 12000 ha, apenas 3.4\% de la superficie ocupada por el latifundio del que había sido cabecera. Para poner esas tierras a salvo de nuevas afectaciones fue necesario dividirlas en tres ranchos o pequeñas propiedades. A principios del siglo XXI eso es lo que queda en manos de la familia de 
aquel "principado en pequeño", el más extenso y espléndido latifundio que hubo en la región.

Aunque algunos hacendados se exiliaron en El Paso o Los Ángeles, mayoritariamente se quedaron en su país, sorteando el temporal y salvando lo que pudieron, lo que los distingue de los aristócratas rusos expulsados por la revolución bolchevique, que terminaron sus días en París "sin dinero, completamente arruinados y trabajando de meseros" (Katz, 1998, t. 2, pp. 25-30; 1994, p. 247).

La fracción de Jaime Rincón, a la que puso el nombre de rancho La Cascarona, la heredó en 2003 su hijo Santiago. Él y su primo Alfonso siguen dedicados al negocio de la engorda de ganado en los agostaderos de Ciénega de Mata, y son actualmente los representantes de una tradición familiar de varios siglos. La hacienda vivió a lo largo de más de tres siglos capítulos de gran esplendor y llegó a ser la capital de un extenso y productivo latifundio; la reforma agraria destruyó esta propiedad y aniquiló el régimen de haciendas en todo el país. Lo que queda a principios del siglo XXI es un par de ranchos ganaderos en pastizales situados a más de 2200 metros de altura sobre el nivel del mar; en palabras de Jaime Rincón Gallardo, el orgulloso e inteligente portador del estandarte familiar durante la segunda mitad del siglo XX, "tierras tan pobres que no merecieron ser repartidas” (Rincón, 1989, p. 12).

\section{LISTA DE REFERENCIAS}

Aboites, L. (2002). El mundo rural del siglo xx. En S. LOAEZA, Gran historia de México ilustrada (t. v, pp. 121-140). México: Planeta/Consejo Nacional para la Cultura y las Artes.

Alcaide, J. (2004). La hacienda Ciénega de Mata de los Rincón Gallardo: un modelo excepcional de latifundio novohispano durante los siglos XVII y XVIII. Guadalajara: Consejo Superior de Investigaciones Científicas/Universidad de Guadalajara.

BARRAGÁn, E. (1994). Rancheros y sociedades rancheras. México: El Colegio de Michoacán. Bazant, J. (1980). Cinco haciendas mexicanas. Tres siglos de vida rural en San Luis Potosí (1600-1910). México: El Colegio de México.

BAZANT, J. (1982). La división de las grandes propiedades rurales mexicanas en el siglo XIX. En H. Moreno, Después de los latifundios. La desintegración de la gran propiedad agraria en México (pp. 31-41). México: El Colegio de Michoacán.

Bazant, J. (1983). Secuestro por infidencia, 1863-1867. Historia Mexicana, 32(4, 128), $574-576$.

Beltrami, J. (1982). Le Mexique. En M. Glantz, Viajes en México. Crónicas extranjeras (Colección SEP/Ochentas, vol. I, pp. 228-234). México: Secretaría de Educación Pública/Fondo de Cultura Económica. 
Am. Lat. Hist. Econ., año 24, núm. 3, septiembre-diciembre, 2017, pp. 130-160

Brading, D. (1988). Haciendas y ranchos del Bajío. León, 1700-1860. México: Editorial Grijalbo.

Chevalier, F. (1976). La formación de los latifundios en México. Tierra y sociedad en los siglos XVI y XVII. México: Fondo de Cultura Económica.

Covo, J. (1983). Las ideas de la Reforma en México, 1855-1861. México: Universidad Nacional Autónoma de México.

Domínguez, Ch. (2004). Vida de fray Servando. México: Era.

Durand, C. (1993). Las reformas y adiciones al artículo 27 constitucional (1857-1992). Alegatos, 24, 1-12.

Epstein, I. (1861). Cuadro sinóptico de Aguascalientes. Aguascalientes: Tipografía de Ávila y Chávez.

Escobar, A. y Gutiérrez, A. M. (coords.) (2009). Entretejiendo el mundo rural en el "oriente" de San Luis Potosí. Siglos XIX y XX. San Luis Potosí: El Colegio de San Luis.

Escobar, A. y Rangel, J. A. (coords.) (2011). Haciendas, negocios y política en San Luis Potosí, siglos XVIII al XX. San Luis Potosí: El Colegio de San Luis.

Friedrich, P. (1984). Revuelta agraria en una aldea mexicana. México: Fondo de Cultura Económica.

FujIGAKI, E. (2006). La agricultura, siglos XVI a XX. En E. SEmo, Historia económica de México (t. 9). México: Universidad Nacional Autónoma de México/Océano.

García, F. (1830). Proyecto de ley sobre el establecimiento de un Banco en Zacatecas y documentos análogos. Zacatecas: s.p.i.

García, G. (1969). El socialismo en México, siglo XIX. México: Era.

García, M. (1992). Hacendados y rancheros queretanos (1780-1920). México: Consejo Nacional para la Cultura y las Artes.

Gómez, J. (2000). Haciendas y ranchos de Aguascalientes: Estudio regional sobre la tenencia de la tierra y el desarrollo agrícola en el siglo XIX. México: Universidad Autónoma de Aguascalientes.

Gómez, J. y Delgado, F. (2005). Un documento de principios del siglo XVIII sobre administración de haciendas. La Memoria de José Rincón Gallardo, Relaciones, 102, 131-160.

GonzÁlez, A. (1887). Informe sobre la agricultura en el estado de Aguascalientes. Informes y documentos relativos a comercio interior y exterior, agricultura, minería e industrias, 23, 136-145.

GonZÁlez, L. (1958). El agrarismo liberal. Historia Mexicana, 7(4), 469-496.

GonzÁlez, L. (1979). Pueblo en vilo. Microhistoria de San José de Gracia. México: El Colegio de México.

Gutelman, M. (1974). Capitalismo y reforma agraria en México. México: Era.

Hale, CH. (1972). El liberalismo mexicano en la época de Mora, 1821-1853. México: Siglo XXI Editores.

Hamnett, B. (1990). Raíces de la insurgencia en México. Historia regional, 1750-1824. México: Fondo de Cultura Económica. 
Hernández, J. E. (2013). José Manuel Plowes Sánchez de Haro: un científico guanajuatense del siglo XIX. Polen-UG, 1(2), 28-29. Recuperado de https://issuu.com/ extensionugto/docs/revistacultural_agosto2013

Hurtado, E. (2004). Aguascalientes: agricultura e irrigación, 1926-1938. Aguascalientes: Consejo de la Crónica de Aguascalientes.

Jovellanos, G. (1979). Informe de la Sociedad Económica de Madrid al Real y Supremo Consejo de Castilla en el expediente de Ley Agraria, extendido por el autor en nombre de la Junta encargada de su formación. Madrid: Ediciones Cátedra.

KATZ, F. (1994). Ensayos mexicanos. México: Alianza.

Katz, F. (1998). Pancho Villa. México: Era.

Knight, A. (1996). La Revolución Mexicana. Del porfiriato al nuevo régimen constitucional. México: Grijalbo.

Knight, A. (2013). Repensar la revolución mexicana. México: El Colegio de México.

Kourí, E. (2013). Un pueblo dividido. Comercio, propiedad y comunidad en Papantla, México. México: Fondo de Cultura Económica.

LADD, D. (1984). La nobleza mexicana en la época de la independencia, 1780-1826. México: Fondo de Cultura Económica.

Leyva, H. (1992). Reforma al artículo 27 de la Constitución Política de Estados Unidos Mexicanos. Revista de la Facultad de Derecho de México, 183-184, 285-302.

Llaguno, J. (1861). Exposición que elevan al Soberano Congreso de la Unión varios propietarios pidiendo la insubsistencia de la llamada Ley Agraria que se publicó en el Estado de Aguascalientes el 17 de agosto último, a cuya exposición se acompañan algunas observaciones escritas sobre la materia. México: Imprenta Literaria.

Manzano, S. (1728). Infórmase en derecho por el que asiste a Don Francisco Xavier Rincón Gallardo, a la propiedad de el vínculo de las haciendas de la Ciénega de Mata, para que se declare inmediato, legítimo y verdadero sucesor en él [...]. México: Joseph Bernardo de Hogal.

Meyer, J. (1983). La fiebre aftosa y la Unión Nacional Sinarquista (1947). Relaciones, $16,88-112$.

Molina, A. (1978). Los grandes problemas nacionales y otros textos. México: Era.

Moreno, A. (1998). Economía regional y urbanización: ciudades y regiones en Nueva España. En J. Silva y J. LóPez, Mercado interno en México (pp. 64-94). México: Instituto de Investigaciones Dr. José María Luis Mora/El Colegio de Michoacán/El Colegio de México/Universidad Nacional Autónoma de México.

Mörner, M. (1975). La hacienda hispanoamericana: examen de las investigaciones y debates recientes. En E. FloresCAnO, Haciendas, latifundios y plantaciones en América Latina, México: Siglo XXI Editores/Consejo Latinoamericano de Ciencias Sociales.

Nickel, H. (1988). Morfología social de la hacienda mexicana. México: Fondo de Cultura Económica.

Olivera, G. (2005). La reforma al artículo 27 constitucional y la incorporación de las tierras ejidales al mercado legal de suelo urbano en México. Scripta Nova. Revis- 
Am. Lat. Hist. Econ., año 24, núm. 3, septiembre-diciembre, 2017, pp. 130-160

ta Electrónica de Geografía y Ciencias Sociales, 9(194). Recuperado de http://www. ub.edu/geocrit/sn/sn-194-33.htm

PAZ, I. (1888). Los hombres prominentes de México. México: Imprenta y Litografía La Patria.

REYES, J. (1982). El liberalismo mexicano (vol. III). México: Fondo de Cultura Económica. Rincón, J. (1989). Ciénega de Mata. Medio siglo, 1939-1989. México: Autor.

Rodríguez, A. (2011). La experiencia olvidada. El Ayuntamiento de México: política y gobierno, 1876-1912. México: El Colegio de México/Universidad Autónoma Metropolitana-Azcapotzalco.

Rojas, B. (1980). La destrucción de la hacienda en Aguascalientes, 1910-1931. Zamora: El Colegio de Michoacán.

Ruvalcaba, H. (2016). La revolución en concreto: el SNR01, 1920-1965 (Tesis doctoral). Universidad Autónoma de Zacatecas, México.

SAlazAR, F. (2011). Hacendados potosinos. Buenos patriotas, buenas recompensas (1866-1867). En A. Escobar y J. A. Rangel, Haciendas, negocios y política en San Luis Potosí, siglos XVIII al XX (pp. 145-162). San Luis Potosí: El Colegio de San Luis.

SÁnchez, M. A. (1975). Agustín Díaz, ilustre cartógrafo mexicano. Historia Mexicana, 96 (XXIV, 4), 556-565.

Schettino, M. (2007). Cien años de confusión. México en el siglo XX. México: Taurus.

SEmo, E. (1988). Historia de la cuestión agraria mexicana. México: Siglo XXI Editores/ Centro de Estudios Históricos del Agrarismo en México.

Sempat, C. (1998). La organización económica espacial del sistema colonial. En J. SiLVA y J. LÓPEZ, Mercado interno en México. Siglos XVIII-XIX (pp. 17-63). México: Instituto de Investigaciones Dr. José María Luis Mora/El Colegio de Michoacán/El Colegio de México/Universidad Nacional Autónoma de México.

SERnA, M. G. (1981). Análisis de una hacienda agropecuaria en el siglo XIX. Ojuelos, 18611880 (Tesis de licenciatura). Universidad Autónoma de Aguascalientes, México.

SERnA, M. G. (1984). Del mayorazgo colonial a la hacienda porfiriana: el caso de Santa Elena de Ojuelos, Jalisco. Relaciones, 19, 29-59.

Serrera, R. (1977). Guadalajara ganadera. Estudio regional novohispano, 1760-1805. Sevilla: Escuela de Estudios Hispanoamericanos.

SILVA, J. (1959). El agrarismo mexicano y la reforma agraria. Exposición y crítica. México: Fondo de Cultura Económica.

Silva, J. (1993). Una vida en la vida de México. México: Siglo XXI Editores.

Tello, C. (1994). El exilio: un relato de familia. México: Cal y Arena.

Tortolero, A. (1998). De la coa a la máquina de vapor. Actividad agrícola e innovación tecnológica en las haciendas mexicanas: 1880-1914. México: Siglo XXI Editores.

Tuttino, J. (2016). Creando un mundo nuevo. Los orígenes del capitalismo en el Bají y la Norteamérica española. México: Fondo de Cultura Económica.

VAldez, R. (1993). Reformas al artículo 27 de la Constitución política de Estados Unidos Mexicanos en materia agraria. En Universidad Nacional Autónoma de México. Instituto de Investigaciones Jurídicas, Modernización del derecho mexicano. 
Reformas constitucionales y legales 1992 (Serie G: Estudios doctrinales, núm. 146, pp. 47-74). México: Autor.

VAn Young, E. (1989). La ciudad y el campo en el México del siglo XVIII. La economía rural de la región de Guadalajara, 1675-1820. México: Fondo de Cultura Económica.

VAN Young, E. (1992). La crisis del orden colonial. Estructura agraria y rebeliones populares de la Nueva España, 1750-1821. México: Alianza Editorial.

WARD, H. (1981). México en 1827. México: Fondo de Cultura Económica.

Warman, A. (1996). La reforma al artículo 27 constitucional. Estudios Agrarios, 2.

Warman, A. (2001). El campo mexicano en el siglo XX. México: Fondo de Cultura Económica.

Womack, J. (1969). Zapata y la revolución mexicana. México: Siglo XXI Editores.

Zayas, P. (s. a.). Las casas Rincón Gallardo y Romero de Terreros. Apuntes genealógicos y biográficos. México: Autor.

\section{Archivos}

ACFrg Archivo Colonial de la Familia Rincón Gallardo, Aguascalientes, México.

AGN Archivo General de la Nación, Ciudad de México, México.

AHEA Archivo Histórico del Estado de Aguascalientes, Aguascalientes, México.

AJMRG Archivo privado del general José María Rincón Gallardo, Aguascalientes, México.

ANL Archivo de Notarías de León, Guanajuato, México.

ARPPL Archivo del Registro Público de la Propiedad de Lagos de Moreno, Jalisco, México. 